\title{
ASPECTOS POLÊMICOS DA INTERCEPTAÇÃO TELEFÔNICA
}

\author{
MARCELO DE LUCA MARZOCHI*
}

Introdução, I) Artigo $5^{\circ}$, incisos X e XII, da Constituição Federal, II) Lei 9296/96, III) Anteprojeto de lei sobre interceptação telefônica, Conclusão, Referênctas bibliográficas, Anexo - Anteprojeto de lei sobre interceptação telefônica

\section{Introdução}

Sempre que há um grande escândalo as gravações de conversas são uma das peças principais. Seja esquema de corrupção, conversas ao celular de traficantes presos, conversas de juízes, de ministros ou até mesmo do presidente da República, a imprensa se esbalda na divulgação do conteúdo das gravações, as quais são muitas vezes consideradas, pela opinião pública, como prova irrefutável de determinado delito.

A Constituição Federal determina no inciso XII, do artigo $5^{\circ}$, a possibilidade de quebra do sigilo das comunicações telefônicas, por meio de atividade de interceptação, apenas nos casos de investigação criminal ou instrução processual penal.

A Lei 9296/96, que regulamentou o inciso XII, do artigo $5^{\circ}$, da Constituição Federal, determina que a interceptação telefônica será realizada para prova em investigação criminal e em instrução processual penal.

Nelson Nery Júnior define prova como o meio processual ou material considerado idôneo pelo ordenamento jurídico para demonstrar a verdade, ou não, da existência e verificação de um fato jurídico. Explica o autor que o juiz deve decidir de acordo com seu livre convencimento motivado, apreciando todo o conjunto probatório. O objeto da prova é o fato controvertido (NERY JÚNIOR, N.; NERY, R.; 2001, pp. 817-819).

* Especialista em Direito Público pela Universidade de Taubaté, em São Paulo. Autor do livro direito.br - Aspectos Jurídicos da Internet no Brasil, publicado pela Editora LTR. 
Fernando da Costa Tourinho Filho define prova como os elementos produzidos pelas partes ou pelo próprio juiz, visando estabelecer dentro do processo a existência de certos fatos. Explica o autor que se entende por fonte de prova tudo quanto possa ministrar indicações úteis cujas comprovações sejam necessárias e que meio de prova é tudo quanto possa servir à comprovação da verdade que se procura no processo. Não se limitam os meios de prova, desde que não se atente contra a moralidade ou se desrespeite a dignidade humana (TOURINHO FILHO, 1998, pp. 219-226).

Importante destacar que a interceptação telefônica isoladamente não pode servir como prova em processo penal, pois não pode materializar a existência do delito capaz de fundamentar uma decisão condenatória. Tanto que o artigo $2^{\circ}$ da Lei 9296/96 determina que ela não será admitida quando a prova puder ser feita por outros meios disponíveis. A interceptação telefônica é meio para se chegar à prova do fato investigado (PARETA, 2003, artigo na Internet, vide referências bibliográficas).

O objetivo deste trabalho é estudar os aspectos mais polêmicos da atividade de interceptação telefônica de acordo com o ordenamento jurídico brasileiro.

\section{$I$ - Artigo $5^{\circ}$, incisos X e XII, da Constituição Federal \\ $\mathrm{O}$ artigo $5^{\circ}$, inciso $\mathrm{X}$, da Constituição Federal determina:}

São invioláveis a intimidade, a vida privada, a honra e a imagem das pessoas, assegurado o direito a indenização pelo dano material ou moral decorrente de sua violação.

Segundo Alexandre de Moraes, pode-se fazer uma diferenciação entre direitos e garantias fundamentais. As disposições meramente declaratórias instituem os direitos, garantindo-lhes existência legal, enquanto as disposições assecuratórias instituem as garantias, pois limitam o poder em defesa dos direitos. Segundo o autor, a eficácia e aplicabilidade das normas que disciplinam os direitos e garantias fundamentais dependem muito de seu próprio enunciado. Em regra, essas normas são de eficácia e aplicabilidade imediatas, como prevê expressamente a própria Constituição Federal (MORAES, A.; 2003, pp. 60-61).

Para Alexandre de Moraes, os conceitos constitucionais de intimidade e vida privada são interligados, podendo ser diferenciados pela menor amplitude do primeiro, que se encontra no âmbito de incidência do segundo. Segundo o autor, intimidade relaciona-se às relações subjetivas e de trato intimo da pessoa, suas relações familiares e de amizade, enquanto vida privada envolve todos os demais relacionamentos humanos, inclusive os objetivos, tais como relações comerciais, de trabalho, de estudo, etc. Ofende o fundamento constitucional da dignidade da pessoa humana, constante no art. $1^{\circ}$ da Constituição Federal, converter em instrumento de diversão ou entretenimento assuntos de natureza íntima que não demonstrem nenhuma finalidade pública e caráter jornalístico em sua divulgação (MORAES, A.; 2003, p. 80). 
José Afonso da Silva explica que a Constituição declara invioláveis a intimidade, a vida privada, a honra e a imagem das pessoas (art. $5^{\circ}, \mathrm{X}$ ). São valores elevados à condição de direito individual, conexos ao direito à vida. Segundo o autor, é preferível utilizar a expressão direito à privacidade, em sentido genérico e amplo, de modo a englobar todas essas manifestações da esfera íntima, privada e da personalidade. A esfera da inviolabilidade é ampla, abrangendo o modo de vida doméstico, relações familiares e afetivas em geral, fatos, hábitos, local, nome, imagem, pensamentos, segredos e as origens e planos futuros do indivíduo. Define privacidade como o conjunto de informação acerca do indivíduo que ele pode decidir manter sob seu exclusivo controle, ou comunicar, decidindo a quem, quando, onde e em que condições, sem a isso poder ser legalmente sujeito. Define intimidade como a esfera secreta da vida do indivíduo na qual este tem o poder legal de evitar os demais. Define vida privada como o direito de o indivíduo viver sua própria vida, pois o segredo da vida privada é condição de expansão da personalidade (SILVA, 2003, pp. 204-208).

Lawrence Lessig define privacidade como o poder de controlar aquilo que os outros podem saber sobre você (LESSIG, 1999, p. 143). A discussão sobre privacidade nos leva logo à figura do "Grande Irmão", de George Orwell no livro "1984". Ou então ao Panóptico, que Sérgio Kulpas assim explica:

O Panóptico, o sistema de vigilância perfeito imaginado por Jeremy Bentham, filósofo e economista do século 18 , pode se tomar plena realidade. A idéia original de Bentham a respeito do Panóptico é analisada e ampliada pelo filósofo Michel Foucault em Vigiar e Punir, obra de 1975. Foucault relaciona o panoptismo como símbolo da transição de um poder visível, o do absolutismo monárquico, que era aplicado com ostentação, tanto em sua pompa como em sua violência, para um poder cada vez mais sem rosto. Poder que não precisa ostentar sua presença porque a sociedade, disciplinada, reproduz "naturalmente" seus mecanismos de controle. Uma idéia de disciplina que surge no final do século 18 , nos quartéis e nos primeiros hospitais modernos, com suas divisões, hierarquias e especificidade de tarefas. A imagem de uma sociedade assim encaixotada e monitorada é mais que um pesadelo literário, é uma fiel descrição de regimes totalitários em que são abolidas as liberdades e os direitos individuais. Ao mesmo tempo pré-requisito e produto da Revolução Industrial, a organização panóptica disciplina os operários nas fábricas - assim como os doentes nos hospitais, alunos nas escolas e presos nas cadeias - , permitindo o aproveitamento dos recursos e do tempo de acordo com as necessidades capitalistas de aceleração da produção. A tecnologia permite já um entrelaçamento circulante de volumes gigantescos das comunicações, entre indivíduos, grupos, empresas, agentes governamentais e financeiros. As disciplinas da vigilância já foram incorporadas há muitas gerações, não são mais percebidas como imposições, com o desconforto de uma ruptura. Na verdade, a multiplicidade das disciplinas disponíveis atualmente dá a impressão de escolha, de livrearbítrio (KULPAS, 2001, pp. 26-27). 
Entretanto, a metáfora mais correia a ser utilizada talvez seja a de Kafka, no livro $O$ Processo. Enquanto em Orwell a figura do Grande Irmão é onipresente, em Kafka o tormento do personagem Joseph K. é não saber o que está acontecendo, porque está sendo processado, quem o está fazendo, como suas informações são manipuladas, qual Tribunal o julgará. E a situação hoje, diante de um mundo globalizado e todo o avanço tecnológico, é bem semelhante à de Joseph K., sensação de impotência, raiva e ansiedade (KAPLAN, 2001, artigo na Internet, vide referências bibliográficas).

Sobre os dilemas da liberdade na sociedade contemporânea, Gilberto Dupas diz o seguinte:

(...) Liberdade, no entanto, também tem muito que ver com proteção da privacidade. $\mathrm{Na}$ sociedade contemporânea, um dos seus mais importantes inimigos é a progressiva construção de uma rede de vigilância que mapeia e controla os atos individuais. Trata-se de um fenômeno global que diz respeito tanto aos consumidores como aos cidadãos; e se refere à maneira como nossas informações pessoais estão sendo armazenadas em bancos de dados computadorizados públicos e privados. David Lyon propõe dois modelos para entender a sociedade contemporânea da vigilância: o Big Brother de Orwell e o Panopticon de Bentham. Em Orwell, o Estado usa seu aparelho burocrático como uma presença onisciente que controla de perto os movimentos e os pensamentos dos cidadãos. A informação e a tecnologia assumem o papel do controle social e acarretam a perda da intimidade, elemento fundamental da dignidade humana, resultando em sociedades despudoradamente transparentes. A vigilância é imperceptível, generalizada e não autorizada pelo cidadão, sendo impossível saber se está só. Já em Bentham, a imagem é de uma prisão semicircular com um órgão de inspeção central que permanece invisível aos cidadãos-prisioneiros. Utilizado por Foucault, esse modelo incorpora a nova forma de disciplina social da modernidade, limpa e racional, que se difunde por todo o tecido social. A formação e o controle de conhecimento especializado aumentam o poder. Poder e conhecimento se realimentam num processo circular. As tecnologias da informação facilitam a convergência das práticas de vigilância no governo e no setor privado. Apesar das alegadas restrições leais e éticas, os containeres de informação pessoal são porosos e circulam assimetricamente de acordo com o poder organizacional e social; são mercadorias preciosas; vendidas legal ou clandestinamente a alto preço e passando de mão em mão, sejam simples informações cadastrais, declarações individuais de rendimento e bens ou de compras por cartão. E esses códigos habilitam, desabilitam, admitem, excluem, conferem crédito e desacreditam, levando à progressiva privatização da cidadania. O grande olho torna-se a arma do desejo, insaciável por mais informação, transformando os detentores do poder - Estados, empresas e indivíduos - em delirantes voyeurs. Aos cidadãos comuns sobram os controles em suas casas, portarias e das baby-sitters, bem como se entregar aos programas de TV ao estilo reality shows. Um mundo tão completamente 
auto-referenciado, que se impõe pela força produtiva das novas tecnologias, é capaz não somente de invadir progressivamente o espaço de liberdade, mas de substituí-la. O problema crítico não está no espaço fundamental que a técnica adquiriu na vida humana e social, mas no fato de que ela se tenha emancipado de sua posição subordinada aos interesses da sociedade (...) (DUPAS, 2003, p. A-2).

Passamos de uma cultura da violência para a cultura da violação, nas palavras de Gilberto de Mello Kujawski, na qual o principal elemento é o propósito de desqualificar, tripudiar e aviltar:

Destruir coisa alheia não passa de simples crime de dano, previsto no Código Penal, mas destruir a coisa pelo que ela representa ou simboliza na memória coletiva, na pátria, na religião, na cultura, muito mais que a violência do dano revela o animus da violação. No caso do estupro, o bem lesado não é o corpo da mulher, e sim sua pessoa, sua liberdade, sua dignidade. Por isso o estupro é sinônimo de violação e vale como seu padrão, sua forma emblemática. Toda violação é um estupro, mesmo quando não está em jogo a sexualidade. Matar por motivo torpe, torturar alguém, destruir um marco histórico, invadir um recinto reservado, afrontar a lei, escarnecer da cultura e das instituições são outras tantas formas de estupro. Toda a violação tem seu emblema no estupro e sua significação simbólica na profanação, no atentado contra o que há de mais sagrado para o homem. Violar é estuprar, e estuprar equivale a profanar. As hostes bárbaras que invadiram Roma agiram como violadores. O 11 de setembro em Nova York foi um surto de violação maniqueísta. E a ameaça de Bush de invadir o Iraque também se caracteriza como violação contra um povo em si inocente. No mundo atroz em que vivemos, a violação tomou o lugar da violência. $\mathrm{E}$ a juventude, na medida em que se afasta da família e da sociedade para imiscuir-se no grupo, volta-se contra a sociedade e a família, por vezes com ânimo de violação. (...) No seio da juventude se desenha atualmente outro tipo de sociedade, visceralmente distinto, não mais uma comunidade de classes centrada na família, e sim uma proliferação indiscriminada de grupos estranhos entre si. Grupos que podem ser inocentes e inofensivos, dedicados a atividades pacíficas, mas que podem degenerar em bandos predadores (pichadores, participantes de "rachas", hackers, etc.) ou em gangues francamente criminosas (narcotraficantes, assaltantes, ladrõezinhos de classe média e alta, etc.). Em nossa época marcada pelo juvenilismo, é o jovem que propõe os modelos dominantes de conduta, inclusive na esfera marginal e criminosa. Os jovens corrompem os mais velhos. Pervertem a violência nesse produto ainda pior que é a violação, o estupro moral, o escarro sobre o sagrado (KUJAWSKI, 2002, p. A-2).

O artigo $5^{\circ}$, inciso XII, da Constituição Federal determina: 
É inviolável o sigilo da correspondência e das comunicações telegráficas, de dados e das comunicações telefônicas, salvo, no último caso, por ordem judicial, nas hipóteses e na forma que a lei estabelecer para fins de investigação criminal ou instrução processual penal.

Damásio E. de Jesus explica o seguinte sobre a garantia constitucional do sigilo das comunicações:

Não se trata de uma garantia absoluta, mas relativa. Significa que lhe são permitidas exceções legítimas no próprio plano da legislação. As garantias individuais previstas na Carta Magna, observa Ada Pellegrini Grinover, "têm sempre feitio e finalidades éticas, não podendo proteger abusos nem acobertar violações". Por isso, "as liberdades públicas não podem ser entendidas em sentido absoluto, em face da natural restrição resultante do princípio da convivência das liberdades, pelo que nenhuma delas pode ser exercida de modo danoso à ordem pública e às liberdades alheias". Em outro trabalho, pondera que é nessa ordem de idéias que deve ser considerada a inviolabilidade do sigilo das comunicações, afirmando: "A garantia constitucional pode sofrer limitações, não devendo prestar-se para a proteção de atividades ilícitas ou criminosas. É assim que, através de uma ponderada apreciação judiciária, que obedeça aos limites legais, pode ser determinada a interceptação das comunicações telefônicas." O direito ao sigilo das comunicações, ensina José Carlos Barbosa Moreira, "é, como qualquer outro, limitado, e não se pode sobrepor de maneira absoluta a todos os restantes interesses dignos de tutela jurídica, por mais relevantes que se mostrem. Aqui tem igualmente lugar a valoração comparativa dos interesses em conflito e a aplicação do princípio da proporcionalidade". Acerca do tema do conflito de interesses, Barbosa Moreira esclarece que sobre o da "preservação da intimidade prevalecem, em linha de princípio, os interesses ligados à reta administração da justiça. Aquele que não pode ter a virtude de obstar ao pleno atendimento destes. Deve atuar aqui, todavia, como alhures, o princípio de que os meios se proporcionam de modo necessário aos fins colimados. $O$ direito à preservação da intimidade sujeita-se ao sacrifício na medida em que a sua proteção seja incompatível com a realização dos objetivos que se têm primariamente em vista. Nessa medida, o ordenamento o tolera ou mesmo o impõe: além dela, não. Cumpre observar um critério de proporcionalidade, com o auxílio do qual se possa estabelecer adequado 'sistema de limites' à atuação das normas suscetíveis de pôr em xeque a integridade da esfera íntima de alguém, participante ou não do processo". A importância de limitar as liberdades públicas, observa Jean Rivero, "resulta da necessidade de torná-las coexistentes, a fim de que possam ser exercidas simultaneamente". Sem dúvida, como diz René Ariel Dotti, "uma vez ditados pelo interesse público ou interesse particular relevante", não se pode "impedir as limitações ou até mesmo o obstáculo ao exercício da privacidade" (JESUS, D.; 2000, pp. 129-130). 
Fernando da Costa Tourinho Filho explica o seguinte:

$\mathrm{O}$ inciso XII cuida de dois grupos de coisas distintas. O primeiro versa sobre a inviolabilidade da correspondência e das comunicações telegráficas. O segundo e último trata dos dados e das comunicações telefônicas. Houvesse sido substituída a disjuntiva "e" entre as palavras "correspondência" e "das comunicações telegráficas" por uma vírgula, a interpretação seria outra. Como está, não. Trata-se de duas hipóteses: a) correspondência e comunicação telegráfica; b) de dados e das comunicações telefônicas (TOURINHO FILHO, 1998, p. 232).

José Afonso da Silva explica:

Trata-se de garantia constitucional que visa assegurar o sigilo da correspondência e das comunicações telegráficas e telefônicas, que são meios de comunicação interindividual, formas de manifestação do pensamento de pessoa a pessoa, que entram no conceito mais amplo de liberdade de pensamento em geral (art. $5^{\circ}$, IV). Ao declarar que é inviolável o sigilo da correspondência e das comunicações telegráficas, de dados e telefônicas, a Constituição está proibindo que se abram cartas e outras formas de correspondência escrita, se interrompa o seu curso e se interceptem telefonemas. Abriu-se excepcional possibilidade de interceptar comunicações telefônicas, por ordem judicial, nas hipóteses e na forma que a lei estabelecer para fins de investigação criminal ou instrução processual. Vê-se que, mesmo na exceção, a Constituição preordenou regras estritas de garantias, para que não se a use para abusos. O objeto de tutela é dúplice: de um lado, a liberdade de manifestação de pensamento; de outro, o segredo como expressão do direito à intimidade (SILVA, J. A.; 2003, p. 436).

Alexandre de Moraes explica:

Apesar de a exceção constitucional expressa referir-se somente à interceptação telefônica, entende-se que nenhuma liberdade individual é absoluta, sendo possível, respeitados certos parâmetros, interceptação de correspondências, comunicações telegráficas e de dados sempre que as liberdades públicas estiverem sendo utilizadas como instrumento de salvaguarda de práticas ilícitas. (...) Importante destacar que a previsão constitucional, além de estabelecer expressamente a inviolabilidade das correspondências e das comunicações em geral, implicitamente proíbe o conhecimento ilícito de seus conteúdos por parte de terceiros (MORAES, 2003, pp. 84-85).

Nelson Nery Júnior explica:

Pelo texto da norma comentada, a inviolabilidade da correspondência e dos dados é absoluta. Nem por ordem judicial poderia ser quebrada, já que 
a parte final do inciso sob comentário só autoriza a quebra judicial do sigilo das comunicações telefônicas. Assim, a contrario sensu, as demais inviolabilidades - incluindo-se a de dados - não podem ser quebradas nem por ordem judicial. (...) Se o Executivo quer quebrar o princípio constitucional da garantia do sigilo dos dados dos cidadãos, deve solicitar essa quebra ao Poder Judiciário, em obediência ao princípio da harmonia entre os poderes do Estado (NERY JÚNIOR, N.; NERY, R.; 2001, p. 19).

O objeto de proteção do inciso XII é o sigilo da correspondência e da comunicação. O legislador foi taxativo, enumerando os tipos de comunicação na redação do texto, para que não houvesse dúvida. Talvez esse tenha sido o maior erro na redação do inciso, pois o legislador não levou em conta o avanço tecnológico, prendendo o texto constitucional a tecnologias já superadas ou que poderiam vir a ser no decorrer do tempo.

Está claro no texto que a expressão "salvo, no último caso" refere-se a "comunicações telefônicas" apenas. A exceção constitucional para violação do sigilo se aplica apenas à "comunicação telefônica", que não se confunde com "comunicação por via telefônica". A primeira trata da transmissão de voz, como explicado pelos dicionários Aurélio e Houaiss no conceito de telefone, enquanto a segunda trata da transmissão de dados. Essa discussão ganha importância por causa do avanço tecnológico, da Internet e pela convergência dos serviços de voz e dados na telefonia.

Vale aqui uma explicação citada por Flávio Lobo sobre o conceito de dado:

No texto Data, Information, Knowledge and Competeny, disponível em sua página na Internet (http://www.ime.usp.br/ vwsetzer), Valdemar Setzer, professor titular de Ciência da Computação na USP, propõe uma compreensão dos termos "dado", "informação" e "conhecimento" bem diferente da que tem sido divulgada pelos arautos da nova era tecnológica. Para Setzer, dados são abstrações formais quantificadas que podem ser armazenadas e processadas por computador. Informações são abstrações informais (não podem ser formalizadas segundo uma teoria matemática ou lógica) que representam, por meio de palavras, som ou imagem, algum significado para alguém. Informações podem ser armazenadas em computador, mas não podem ser processadas (para isso seria preciso quantificá-las, reduzindo-as a dados). Enquanto dados são puramente sintéticos, informações contêm semântica. Conhecimento é uma abstração interna e pessoal gerada a partir da experiência. Nesse sentido, não pode ser completamente descrito, representado, caso contrário seria apenas informação. Portanto, o conhecimento não pode ser armazenado nem processado por um computador (LOBO, 2000, p. 22).

Luciana Fregadolli, citando Vicente Greco Filho sobre esta questão, diz que não se confundem comunicações "telefônicas" e "por meio de linha telefônica", uma vez que telefone é aparelho de comunicação de voz, de modo que os instrumentos que se utilizam da linha telefônica somente por essa razão podem ser a ele equiparados. Afirma a autora que se a Constituição quisesse essa extensão teria usado a 
expressão "comunicação por linha telefônica". Portanto, não se aplica a autorização constitucional de interceptação às comunicações de dados. Afirma ainda a autora que a garantia constitucional do sigilo é a regra e a interceptação, que deve ser restritiva, a exceção (FREGADOLLI, 1998, pp. 99-103).

\section{II - Lei 9296/96}

A Lei 9296/96 que regulamenta o inciso XII, parte final, do art. $5^{\circ}$ da Constituição Federal, trata da interceptação de comunicações telefônicas, de informática e telemática.

A íntegra da lei é a seguinte:

Art. $1^{\circ}$ - A interceptação de comunicações telefônicas, de qualquer natureza, para prova em investigação criminal e em instrução processual penal, observará o disposto nesta Lei e dependerá de ordem do juiz competente da ação principal, sob segredo de justiça.

Parágrafo único - O disposto nesta Lei aplica-se à interceptação do fluxo de comunicações em sistemas de informática e telemática.

Art. $2^{\circ}$ - Não será admitida a interceptação de comunicações telefônicas quando ocorrer qualquer das seguintes hipóteses:

I - não houver indícios razoáveis da autoria ou participação em infração penal;

II - a prova puder ser feita por outros meios disponíveis;

III - o fato investigado constituir infração penal punida, no máximo, com pena de detenção.

Parágrafo único - Em qualquer hipótese deve ser descrita com clareza a situação objeto da investigação, inclusive com a indicação e qualificação dos investigados, salvo impossibilidade manifesta, devidamente justificada. Art. $3^{\circ}-\mathrm{A}$ interceptação das comunicações telefônicas poderá ser determinada pelo juiz, de ofício ou a requerimento:

I - da autoridade policial, na investigação criminal;

II - do representante do Ministério Público, na investigação criminal e na instrução processual penal.

Art. $4^{\circ}$ - O pedido de interceptação de comunicação telefônica conterá a demonstração de que a sua realização é necessária à apuração de infração penal, com indicação dos meios a serem empregados.

$\S 1^{\circ}$ Excepcionalmente, o juiz pode admitir que o pedido seja formulado verbalmente, desde que estejam presentes os pressupostos que autorizem a interceptação, caso em que a concessão será condicionada à sua redução a termo.

$\S 2^{\circ} \mathrm{O}$ juiz, no prazo máximo de vinte e quatro horas, decidirá sobre o pedido.

Art. $5^{\circ}$ - A decisão será fundamentada, sob pena de nulidade, indicando também a forma de execução da diligência, que não poderá exceder o prazo 
de quinze dias, renovável por igual tempo uma vez comprovada a indispensabilidade do meio de prova.

Art. $6^{\circ}$ - Deferido o pedido, a autoridade policial conduzirá os procedimentos de interceptação, dando ciência ao Ministério Público, que poderá acompanhar a sua realização.

$\S 1^{\circ}$ No caso de a diligência possibilitar a gravação da comunicação interceptada, será determinada a sua transcrição.

$\S 2^{\circ}$ Cumprida a diligência, a autoridade policial encaminhará o resultado da interceptação ao juiz, acompanhado de auto circunstanciado, que deverá conter o resumo das operações realizadas.

$\S 3^{\circ}$ Recebidos esses elementos, o juiz determinará a providência do art. $8^{\circ}$, dente o Ministério Público.

Art. $7^{\circ}$ - Para os procedimentos de interceptação de que trata esta lei, a autoridade policial poderá requisitar serviços e técnicos especializados às concessionárias de serviço público.

Art. $8^{\circ}$ - A interceptação de comunicação telefônica, de qualquer natureza, correrá em autos apartados, apensados aos autos do inquérito policial ou do processo criminal, preservando-se o sigilo das diligências, gravações e transcrições respectivas.

Parágrafo único - A apensação somente poderá ser realizada imediatamente antes do relatório da autoridade, quando se tratar de inquérito policial (Código de Processo Penal, art: $10, \S 1^{\circ}$ ) ou na conclusão do processo ao juiz para o despacho decorrente do disposto nos arts. 407, 502 ou 538 do Código de Processo Penal.

Art $9^{\circ}$ - A gravação que não interessar à prova será inutilizada por decisão judicial, durante o inquérito, a instrução processual ou após esta, em virtude de requerimento do Ministério Público ou da parte interessada.

Parágrafo único - O incidente de inutilização será assistido pelo Ministério Público sendo facultada a presença do acusado ou de seu representante

Art. 10 - Constitui crime realizar interceptação de comunicações telefônicas, de informática ou telemática, ou quebrar segredo da Justiça, sem autorização judicial ou com objetivos não autorizados em lei.

Pena: reclusão, de dois a quatro anos, e multa.

Art. 11 - Esta Lei entra em vigor na data de sua publicação.

Art. 12 - Revogam-se as disposições em contrário.

Damásio E. de Jesus diz o seguinte sobre a Lei 9296/96:

$\mathrm{Na}$ interceptação telefônica há três protagonistas: dois interlocutores e o interceptador, que capta a conversação sem consentimento daqueles. $\mathrm{Na}$ escuta telefônica há também dois interlocutores e um interceptador, só que um daqueles tem conhecimento do fato. Na gravação clandestina há só dois comunicadores, sendo que um deles grava a conversação. A Lei 9296/96 é aplicável às duas primeiras formas de interceptação. Não, porém, à terceira. Ela não incide sobre a "gravação clandestina" ou a "escuta telefônica", 
nem proíbe a violação de comunicação de outra natureza, como a postal, telegráfica, via telex, etc. A interceptação telefônica possui natureza jurídica de medida cautelar. Seus requisitos: $1^{\circ}$ ) Ordem judicial emanada de juiz competente para o processo-crime; $2^{\circ}$ ) Escuta realizada por serviços técnicos especializados de concessionárias de serviço público; $3^{\circ}$ ) Motivação. A interceptação, como diz Ada Pellegrini Grinover, é considerada meio de apreensão imprópria de prova, uma vez que "configura operação técnica, através da qual se permite apreensão, não de uma carta ou de um documento, mas sim dos elementos fonéticos que constituem a conversa telefônica". Assim, o resultado da interceptação deve ser considerado fonte de prova, cuja busca e apreensão sujeitam-se à autorização judicial, adotando-se o princípio da verificação prévia. (...) Segundo nossa posição, não se exige que a interceptação se faça durante a ação penal, podendo ser autorizada na fase do inquérito policial ou mesmo antes de sua instauração, desde que razões a justifiquem. (...) Quanto à finalidade da escuta telefônica no processo penal, destina-se à produção de prova no que tange à demonstração da existência do fato material (conduta, resultado e nexo de causalidade), de sua ilicitude ou da culpabilidade do sujeito. (...) A norma se estende à interceptação do fluxo de comunicações em sistemas de informática e telemática. Informática é a ciência relativa à informação por intermédio de equipamentos e métodos do sistema de processamento de dados. Telemática é a ciência que versa sobre a informação por meio do conjunto de computador e telecomunicação ("tele" de telecomunicação + "mática" de informática). Ex.: Comunicações via modem. Como diz o caput do dispositivo, trata de comunicação telefônica "de qualquer natureza". A Carta Magna, ao excepcionar o sigilo das comunicações, não faz referência aos sistemas de informática e telemática (art. $5^{\circ}$, XII). Em face disso, há duas correntes a respeito de sua constitucionalidade: $1^{\circ}$ ) é inconstitucional, uma vez que a CF só admite a violação do sigilo da comunicação telefônica. (...) $2^{\circ}$ ) o dispositivo é constitucional, entendendo-se que a Carta Magna admite a interceptação de qualquer comunicação "por meio de telefone". (...) Inclinamo-nos pela constitucionalidade do referido parágrafo único. A Carta Magna, quando excepciona o princípio do sigilo na hipótese de "comunicações telefônicas", não cometeria o descuido de permitir a interceptação somente no caso de conversação verbal por esse meio, quando usados dois aparelhos telefônicos, proibindo-a quando pretendida com finalidade de investigação criminal e prova em processo penal, nas hipóteses mais modernas. A exceção, quando menciona "comunicações telefônicas", estendese a qualquer forma de comunicação que empregue a via telefônica como meio, ainda que haja transferência de "dados". É o caso do uso do modem. Se assim não fosse, bastaria, para burlar a permissão constitucional, "digitar" e não "falar". A alegação de que o fluxo de comunicações cuide-se de informática ou telemática, faz-se mediante transmissão de dados não impressiona. A circunstância de a CF expressamente só abrir exceção no caso da comunicação telefônica não significa que o legislador ordinário não possa 
permitir a interceptação na hipótese de transmissão de "dados". Não há garantias constitucionais absolutas (JESUS, D.; 2000, pp. 131-135).

Nelson Nery Júnior diz, sobre a Lei 9296/96, que a norma constitucional permite apenas a interceptação das conversas por voz entre pessoas e que as demais comunicações pela linha telefônica como modem, fax e Internet não podem ser interceptadas. Conclui o autor que, por essa razão, o artigo primeiro da lei é inconstitucional por estender, sem autorização constitucional, às comunicações de informática e telemática, a exceção prevista apenas para comunicações telefônicas (NERY JÚNIOR, N.; NERY, R.; 2001, p. 2172).

Fernando da Costa Tourinho Filho explica os principais pontos dessa lei:

Como se trata de medida excepcional, o legislador, ao permitir a quebra do sigilo, estabeleceu uma série de exigências. Assim, nessas interceptações, indispensável a observância das seguintes regras:

1) Devem ser realizadas por determinação exclusiva do Juiz da causa para prova em investigação criminal e em instrução processual penal, vedadas, de conseguinte, em causas cíveis;

2) Podem ser determinadas de ofício, ou a requerimento da Autoridade Policial (na fase do inquérito);

3) Serão realizadas sob segredo de justiça;

4) Não serão permitidas quando ocorrer uma das seguintes hipóteses: a) não houver indícios razoáveis da autoria ou participação em infração penal; b) a prova puder ser feita por outros meios disponíveis; c) o fato investigado constituir infração penal punida, no máximo, com detenção;

5) Em qualquer hipótese deve ser descrita com clareza a situação objeto da investigação, inclusive com indicação e qualificação dos investigados;

6) O pedido deverá conter a demonstração de que a sua realização é necessária à apuração de infração penal, com indicação dos meios a serem empregados;

7) Excepcionalmente, o pedido pode ser formulado verbalmente (reduzindo-se a termo), desde que satisfeitos os pressupostos de admissibilidade;

8) $\mathrm{O}$ ato permissivo deverá ser fundamentado, sob pena de nulidade, indicando também a forma de execução da diligência;

9) Esta deverá ser realizada no prazo de 15 dias, renovável por igual período, se comprovada a indispensabilidade desse meio de prova;

10) A diligência fica a cargo da autoridade policial, podendo o Ministério Público acompanhá-la;

11) A autoridade policial poderá requisitar serviços técnicos especializados às concessionárias de serviços públicos;

12) Realizada a diligência, seu resultado e eventuais transcrições serão objeto de autos apartados e que serão apensados ao inquérito, antes do relatório, ou ao processo, quando os autos forem conclusos ao Juiz para o despacho decorrente do disposto nos arts. 407, 502 e 538 do Código de Processo Penal; 
13) Será preservado o sigilo das diligências, gravações e transcrições respectivas;

14) As gravações que não interessarem à prova serão inutilizadas, presente o órgão do Ministério Público. E para resguardar o direito à privacidade a lei estabeleceu no seu art. 10 constituir crime punido com 2 a 4 anos de reclusão e multa realizar interceptação, ou quebrar segredo de Justiça, sem autorização judicial ou com objetivos não autorizados em lei (TOURINHO FILHO, 1998, p. 233).

O primeiro equívoco do legislador foi ter usado a palavra interceptar, pois esta significa interromper o fluxo de uma coisa, pôr obstáculo a, impedir, cortar, deter, fazer parar. O correio deveria ser captar, pois englobaria todas as formas de se tomar conhecimento da comunicação.

O segundo equívoco está no parágrafo único do artigo primeiro. O legislador igualou comunicações telefônicas às "de informática e telemática". Uma é completamente diferente da outra. A comunicação telefônica consiste na transmissão da voz, da conversação. E a de "informática e telemática" consiste na transmissão de dados (MARZOCHI, 2000, p. 25).

Há uma discussão, tanto na doutrina quanto na jurisprudência, no âmbito tributário, sobre a incidência de ICMS ou ISS, no caso de a Internet, por utilizar a linha telefônica, ser serviço de telecomunicação ou serviço de valor adicionado nos termos dos artigos 60 ou 61 da Lei 9472/97, que regulamentou a atividade de telecomunicação e criou a Agência Nacional de Telecomunicações. Esses artigos estabelecem:

Art. 60 - Serviço de telecomunicações é o conjunto de atividades que possibilita a oferta de telecomunicação.

$\S 1^{\circ}$ Telecomunicação é a transmissão, emissão ou recepção, por fio, radioeletricidade, meios ópticos ou qualquer outro processo eletromagnético, de símbolos, caracteres, sinais, escritos, imagens, sons ou informações de qualquer natureza.

Art. 61 - Serviço de valor adicionado é a atividade que acrescenta, a um serviço de telecomunicações que lhe dá suporte e com o qual não se confunde, novas utilidades relacionadas ao acesso, armazenamento, apresentação, movimentação ou recuperação de informações.

$\S 1^{\circ}$ Serviço de valor adicionado não constitui serviço de telecomunicações, classificando-se seu provedor como usuário do serviço de telecomunicações que lhe dá suporte, com os direitos inerentes a essa condição.

A importância dessa discussão para o Processo Penal está no fato de o Anteprojeto do Ministério da Justiça sobre a nova lei de interceptação telefônica, estudado no item III deste trabalho, se fundamentar nos dois artigos da Lei 9472/97 acima citados para igualar as comunicações telefônicas a toda e qualquer forma de telecomunicação, para assim permitir a interceptação. 
Há decisões da jurisprudência que vão no sentido de considerar a Internet serviço de telecomunicação, como no julgado abaixo:

BRASIL, Superior Tribunal de Justiça. Recurso Especial: RESP 323358/PR, Primeira Turma. Relator: Min. José Delgado, 21/6/2001.

TRIBUTÁRIO. PROVEDOR DA INTERNET. PRESTAÇÃO DE SERVIÇO DE COMUNICAÇÃO, ESPÉCIE DE SERVIÇO DE TELECOMUNICAÇÃO. RELAÇÃO DE NATUREZA NEGOCIAL COM O USUÁRIO. FATO GERADOR DE ICMS DETERMINADO. INCIDÊNCIA. LEI COMPLEMENTAR No 87/1996. LEI No 9.472/1997. Recurso Especial interposto contra v. Acórdão que entendeu que "o provedor de acesso à internet não presta serviço de comunicação ou de telecomunicação, não incidindo sobre a atividade por ele desempenhada o ICMS". O Provedor da Internet é um agente interveniente prestador de serviços de comunicação, definindo-o como sendo "aquele que presta, ao usuário, um serviço de natureza vária, seja franqueando o endereço na INTERNET, seja armazenando e disponibilizando o site para a rede, seja prestando e coletando informações etc. É designado, tecnicamente, de Provedor de Serviços de Conexão à INTERNET (PSC), sendo a entidade que presta o serviço de conexão à INTERNET (SCI)". (Newton de Lucca, em artigo "Títulos e Contratos Eletrônicos", na obra coletiva Direito e INTERNET, pág. 60.) O provedor vinculado à INTERNET tem por finalidade essencial efetuar um serviço que envolve processo de comunicação exigido pelo cliente, por deter meios e técnicas que permitem o alcance dessa situação fática. O serviço prestado pelos provedores está enquadrado como sendo de comunicação, espécie dos serviços de telecomunicações. A Lei Complementar no 87, de 13/09/1996, estabelece, em seu art. $2^{\circ}$, que incide o ICMS sobre "prestações onerosas de Serviços de Comunicação, por qualquer meio, inclusive a geração, a emissão, a recepção, a transmissão, a retransmissão, a repetição, a ampliação de comunicação de qualquer natureza", círculo que abrange os serviços prestados por provedores ligados à INTERNET, quando os comercializam. Qualquer serviço oneroso de comunicação está sujeito ao pagamento do ICMS. A relação entre o prestador de serviço (provedor) e o usuário é de natureza negocial visando possibilitar a comunicação desejada. É suficiente para constituir fato gerador de ICMS. O serviço prestado pelo provedor pela via da Internet não é serviço de valor adicionado, conforme o define o art. 61, da Lei ${ }^{\circ} 9.472$, de 16/07/1997. Recurso provido.

Internet é transmissão de dados. Ao se considerar a transmissão de dados como telecomunicação, confirma-se a sua inviolabilidade prevista no inciso XII, do artigo $5^{\circ}$, só se aplicando a exceção constitucional às comunicações telefônicas.

Portanto. a prova obtida com a violação do sigilo de qualquer outro tipo de comunicação que não seja a telefônica é ilícita. O inciso LVI, do artigo $5^{\circ}$, da 
Constituição Federal estabelece que são inadmissíveis, no processo, provas obtidas por meios ilícitos.

Prova ilícita é a que decorre da violação de norma do direito material, obtida através de ato ilícito. As que derivam de violação de norma processual são chamadas ilegítimas.

Não se pode confundir prova ilícita com prova atípica, pois a ilicitude decorre da violação de um bem jurídico, e não da falta de previsão legal (VASCONCELLOS, R.; 2001, p. 457).

Mesmo sendo ilícita, a prova obtida através de interceptação das comunicações de informática e telemática poderá ser admitida no processo?

Há diversos julgados que admitem a teoria da proporcionalidade em relação à prova ilícita, não considerando absolutas as garantias constitucionais quando, principalmente, o interesse público está em jogo. Há também diversos doutrinadores neste sentido.

Para Maria Cecília Pontes Carnaúba as garantias individuais não serão afetadas com o emprego da proporcionalidade para a análise da licitude de provas, porque esta teoria se fixa em três pontos: necessidade, adequação e proporcionalidade em sentido estrito. Para a autora, a necessidade se traduz numa situação em que não poderia ser adotado outro método, igualmente eficaz, que limitasse de maneira menos gravosa o direito fundamental. A adequação significa que os meios adotados sejam idôneos para o alcance do objetivo perseguido. E a proporcionalidade em sentido estrito é o critério empregado para aferir se o meio necessário e adequado que se utilizou é proporcional à finalidade perseguida (CARNAÚBA, 2000, p. 93).

Entendimento diverso tem Ricardo Rangel, para o qual a utilização da prova ilícita com base na teoria da proporcionalidade só seria possível se fosse feita pela defesa. Diz o autor:

(...) a busca da verdade real, fonte fundamentadora da amplitude dos meios de provas, encontra limites decorrentes dos Princípios Constitucionais de proteção e garantia aos direitos individuais. A busca da verdade real, escopo da ação penal, consiste em uma reconstrução histórica, sendo inclusive insuficiente para a definição da lide a confissão do acusado, pois não existe no processo penal prova absoluta ou incontroversa. Mas esta busca (recomenda-se inclusive que seja exaustiva) não pode transgredir direitos individuais, aviltando a honra e dignidade humanas. Este sistema de respeito às garantias fundamentais pode gerar erros equívocos, mas é tolerável, constituindo-se no preço a ser pago na vivência de um Estado de Direito. (...) A Teoria da Proporcionalidade aplica-se com clareza quando a prova teoricamente ilícita é pro reo, não somente por que o Princípio da Ampla Defesa é assegurado a todos os acusados em processos judiciais, mas também porque, nestes casos, quando a prova teoricamente ilícita for colhida para ser usada na defesa, tem-se entendido que a ilicitude é eliminada por causas legais como a legítima defesa ou estado de necessidade, que exclui a ilicitude do ato. Os valores confrontados nos dois casos são diferentes, pois a prova ilícita produzida pelo Estado e seus agentes, a título de defesa da sociedade 
não procede, pois nesta o interesse é o da punição, enquanto que, no outro caso, o interesse é tutelar a liberdade e a inocência (RANGEL, R. M. B.; 2000, pp. 52-53 e 83-84).

$\mathrm{O}$ interesse público teria maior relevância que quaisquer outros interesses a serem protegidos, e nesses casos a utilização de provas ilícitas seria possível. Entretanto, a teoria da proporcionalidade dá margem a abusos. Quantas vezes ao longo da história foram cometidos abusos em nome do interesse coletivo?

Um exemplo é um sistema de monitoração nos moldes do americano Echelon. Esse sistema era utilizado na Guerra Fria para espionagem. Com a queda do Muro de Berlim e o fim do comunismo foi direcionado para espionagem industrial. Possui bases espalhadas pelo mundo, capazes de captar qualquer tipo de comunicação por satélite, do telefone ao correio eletrônico (MARZOCHI, 2000, pp. 31-32).

No ano 2000, nos Estados Unidos, foi colocado em operação pelo FBI, nos Estados Unidos, um sistema que permite a análise e extração de qualquer informação da Internet, o chamado "Carnívoro". Na Inglaterra foi aprovada uma lei que amplia o direito do governo na vigilância eletrônica, possibilitando a extração e análise de qualquer informação. Na Holanda uma empresa de segurança reconheceu que recolhia mensagens de correio eletrônico que empresas mandavam ao exterior, e em Haia estavam sendo elaboradas leis que davam amplos poderes ao governo para fazer vigilância eletrônica, inclusive monitorar o movimento de usuários (CAMPBELL, 2000, p. B-16).

Após os atentados terroristas de 11 de setembro de 2001, em Nova York, os Estados Unidos iniciaram uma cruzada contra o terrorismo utilizando-se de todos os mecanismos possíveis de vigilância e restrição à liberdade. O "Grande Irmão" de Orwell nunca foi tão real.

A interpretação das garantias constitucionais deve ser restritiva. As normas constitucionais devem ser interpretadas em favor do cidadão. $\mathrm{O}$ artigo $5^{\circ}$ da Constituição Federal deve ser visto não apenas como um elenco de garantias e direitos, mas também como um limite para a ação do Estado.

A teoria dos frutos da árvore venenosa, em relação à Lei 9296/96, é a mais aceitável porque evita o abuso, principalmente os cometidos pelo Poder Público, que a teoria da proporcionalidade possibilita (MARZOCHI, 2000, p. 32).

Venenosa a árvore, venenoso o fruto e venenoso o doce feito do fruto.

Portanto, a prova obtida de acordo com a Lei 9296/96 em relação a interceptação de comunicação que não seja a telefônica é ilícita, sendo inadmissível no processo de acordo com a teoria dos frutos da árvore venenosa.

\section{III - Anteprojeto de lei sobre interceptação telefônica}

A íntegra do Anteprojeto do Ministério da Justiça está no anexo 2.

$\mathrm{Na}$ Exposição de Motivos do anteprojeto os autores Ada Pellegrini Grinover, Antônio Carlos de Almeida Castro, Antônio Magalhães Gomes Filho, Antônio Scarance Fernandes e Luis Guilherme Vieira afirmam no item l que a regulamentação 
dessa matéria deverá resultar da ponderação dos valores em jogo, observando-se o princípio da proporcionalidade, entendido como o justo equilíbrio entre os meios empregados e os fins a serem alcançados. E essa proporcionalidade deve apresentar os seguintes requisitos: a) adequação - a aptidão da medida para atingir os objetivos pretendidos; b) necessidade - a exigência de se limitar um direito para proteger outro igualmente relevante; c) proporcionalidade estrita - a ponderação entre a restrição imposta e a vantagem alcançada; d) não-excessividade.

Os autores, no item 2, ainda enumeram os defeitos da Lei 9296/96:

O defeito maior da vigente Lei 9.296, de 24 de julho de 1996, que dispõe sobre interceptações telefônicas e de fluxo de comunicações em sistemas de informática e telemática, talvez consista exatamente na inobservância do princípio da proporcionalidade, quando, por exemplo, permite a interceptação relativamente a todos os crimes punidos com pena de reclusão - no que não observa o princípio da adequação e da não-excessividade, estendendo a operação técnica indicada para qualquer tipo de crime, desde que punido com reclusão, e deixando de fora crimes punidos com detenção, mas para os quais a interceptação se apresenta como o meio mais adequado de investigação, como na ameaça cometida por telefone; quando permite o pedido formulado verbalmente, o que evidentemente corrói a verificação da necessidade e da adequação. Mas há outros graves defeitos na lei, como quando transborda da autorização constitucional para prever interceptações de comunicações em sistemas de informática; quando não permite ao acusado o pedido de interceptação; quando não dá vista ao MP do requerimento da diligência pela autoridade policial; quando não dispõe com clareza sobre o incidente probatório no qual deve dar-se conhecimento às partes do conteúdo das operações técnicas, em contraditório pleno; quando omite completamente o tratamento das chamadas "interceptações ambientais"; quando considera a interceptação como único meio de intromissão legal numa comunicação telefônica, olvidando o impedimento, a interrupção, a escuta e gravação. E, sobretudo, a lei em vigor não cuida dos controles necessários a evitar os abusos a que freqüentemente sua aplicação deu margem: controles sobre a representação e requerimento da polícia e do Ministério Público, controles sobre a autorização judicial e a forma de seu encaminhamento, controles mais rigorosos sobre os prazos e, sobretudo, controles sobre as operações técnicas, hoje deixadas exclusivamente a critério da autoridade policial, sem a fixação de qualquer parâmetro.

No item 4 da Exposição de Motivos os autores explicam cada um dos trinta artigos.

O Anteprojeto é um avanço porque acaba com pontos obscuros deixados pela Lei $9296 / 96$.

Entretanto, os dois pecam no mesmo ponto ao igualarem formas diferentes de comunicação. O parágrafo único, do artigo $1^{\circ}$, da Lei $9296 / 96$ determina que se aplicam as mesmas disposições da interceptação telefônica à interceptação das co- 
municações de informática e telemática. O parágrafo único, do artigo $1^{\circ}$, do Anteprojeto equipara comunicações telefônicas a todas as formas de telecomunicação e faz-se referência ao parágrafo único, do artigo 60, da Lei 9472/97. No item 4 da Exposição de Motivos afirma-se que às comunicações telefônicas são equiparadas todas as formas de telecomunicações previstas na Lei 9472/97.

Todavia, o parágrafo único, do artigo 60. da Lei 9472/97, já citado anteriormente neste trabalho, limita-se apenas a definir o que é telecomunicação e de modo algum equipara todas as formas de comunicação à telefonia.

Ao menos se melhorou a técnica legislativa, ao se abandonar a redação negativa do artigo $2^{\circ}$, da Lei 9296/96, que determina as hipóteses nas quais não será admitida a interceptação telefônica, pela redação afirmativa do artigo $1^{\circ}$ do Anteprojeto, que determina os casos de admissibilidade da interceptação assim como as técnicas a serem aplicadas.

\section{Conclusão}

A situação na qual nos encontramos hoje é de insegurança jurídica.

Há sempre uma discussão apaixonada sobre este tema, principalmente quando se descobre algum grande escândalo através de uma interceptação telefônica e se passa a se defender o uso amplo e irrestrito deste procedimento para qualquer investigação.

A interceptação de comunicação telefônica, entendida como comunicação de voz entre pessoas, é meio lícito para obtenção de prova desde que obedecidos os requisitos da Constituição Federal e da Lei 9296/96.

O problema se dá quando se trata de comunicação de dados que, com o avanço tecnológico, se tornou comum nos dias de hoje, principalmente com a convergência dos serviços de voz e dados na telefonia.

$\mathrm{O}$ inciso XII, do artigo $5^{\circ}$, proibe a violação do sigilo de qualquer tipo de comunicação, abrindo exceção para a telefônica no caso de investigação criminal ou instrução processual penal, com a devida autorização judicial.

Tanto a Lei 9296/96 quanto o Anteprojeto pecam no mesmo ponto, quando igualam diferentes formas de comunicação. Na primeira se iguala comunicação telefônica com a de informática e telemática, enquanto no segundo se iguala à comunicação telefônica todas as outras formas de telecomunicação, fazendo-se referência ao artigo 60 da Lei 9472/97, o qual se limita a simples definição do que é telecomunicação.

Deve-se ter sempre em mente que o sigilo das comunicações é regra, a interceptação a exceção. Por isso deve ser um procedimento restrito, observando-se sempre as garantias e os direitos individuais.

\section{Referências bibliográficas}

ABUD, Maria José Milharezi. Didática e Metodologia do Ensino Superior. Notas de aula, 2003. 
CAMELLO, Maurílio José. Metodologia Científica. Notas de aula, 2003.

CAMPBELL, Duncan. "Vigilância na Internet cresce e causa polêmica". O Estado de São Paulo. São Paulo, 13 de agosto de 2000. Economia, p. B-16.

CARNAÚBA, Maria Cecília Pontes. Prova Ilícita. São Paulo: Saraiva, 2000.

DUPAS, Gilberto. "Dilemas da liberdade". O Estado de São Paulo. São Paulo, 28 de junho de 2003. Primeiro Caderno, p. A-2.

FREGADOLLI, Luciana. O Direito à Intimidade e a Prova Ilícita. Belo Horizonte: DelRey, 1998.

JESUS, Damásio E. de. Código de Processo Penal Anotado. São Paulo: Saraiva, 2000.

KAPLAN, Carl. "Kafkaesque? Big Brother? Finding the right literary metaphor for Net Privacy". The New York Times, 2 de fevereiro de 2001, no endereço http://www.nytimes.com.

KULPAS, Sérgio. "Um Protótipo", In: KUJAWSKI, Guilherme. "Se liga, cidadão". Carta Capital. São Paulo, n 147, pp. 26-27, 23 de maio de 2001.

KUJAWSKI, Gilberto de Mello. "A cultura da violação". O Estado de São Paulo. São Paulo, 28 de novembro de 2002. Primeiro Caderno, p. A-2.

LESSIG, Lawrence. Code and other Laws of cyberspace. N. York: Basic Books, 1999.

LOBO, Flávio. "A Era da Ignorância". Carta Capital. São Paulo, 6 de dezembro de $2000, n^{\circ} 137$, p. 22.

MARZOCHI, Marcelo De Luca. Direito.br - Aspectos Jurídicos da Internet no Brasil. São Paulo: LTR, 2000.

MORAES, Alexandre de. Direito Constitucional. São Paulo: Atlas, 13a ed., 2003.

NERY JÚNIOR, Nelson e NERY, Rosa Maria de Andrade. Código de Processo Civil Comentado. São Paulo: Revista dos Tribunais, 2001.

PARETA, Ivan. A interceptação telefônica e a prova, no endereço http://www.direitoemdebate.net/art_intercepcaotel.html, acessado em novembro de 2003.

PONTIFÍCIA UNIVERSIDADE CATÓLICA DE CAMPINAS, FACULDADE DE BIBLIOTECONOMIA E PROJETO DISQUE-BIBLIO. Normalização de Trabalhos Acadêmicos. Campinas: Diretório Central dos Estudantes - Gestão Sempre ous@r, 1997.

RANGEL, Ricardo Melchior de Barros. A Prova Ilícita e a Interceptação Telefônica no Direito Processual Penal Brasileiro. Rio de Janeiro: Forense, 2000.

SILVA, José Afonso da. Curso de Direito Constitucional Positivo. São Paulo: Malheiros, $22^{\mathrm{a}}$ ed., 2003.

TOURINHO FILHO, Fernando da Costa. Processo Penal. São Paulo: $20^{\mathrm{a}}$ ed., v. 3 , 1998.

UNIVERSIDADE DE TAUBATÉ. Normas para elaboração e apresentação de monografias de conclusão de cursos de especialização, dissertações de mestrado $e$ teses de doutorado. Pró-reitoria de Pesquisa e Pós-graduação. Taubaté, 2001.

VASCONCELLOS, Roberto Prado de. "Provas Ilícitas (Enfoque Constitucional)". Revista dos Tribunais. São Paulo: Revista dos Tribunais, v. 791, pp. 456-486, setembro 2001. 
Anteprojeto de lei sobre interceptação telefônica. Fonte: Ministério da Justiça, no endereço http://www.mj.gov.br/sal, em novembro de 2003.

\section{EXPOSIÇÃO DE MOTIVOS}

1 - A quebra do sigilo de comunicações telefônicas, excepcionalmente admitida pela Constituição Federal, na parte final do inciso XII do artigo $5^{\circ}$, exclusivamente para fins de investigação criminal e instrução processual penal, constitui, certamente, poderoso meio posto à disposição do Estado para fins de obtenção da prova, mas também instrumento insidioso de quebra da intimidade, não só do investigado, como também de terceiros. Por isso, diante do princípio da reserva de lei proporcional, a regulamentação da matéria há de resultar da escrupulosa ponderação dos valores em jogo, observando o princípio da proporcionalidade, entendido como justo equilíbrio entre os meios empregados e os fins a serem alcançados. E a proporcionalidade deve levar em conta os seguintes dados: a — adequação, ou seja a aptidão da medida para atingir os objetivos pretendidos; $\mathrm{b}$ - necessidade, como exigência de limitar um direito para proteger outro, igualmente relevante; c) proporcionalidade estrita, ou seja, a ponderação entre a restrição imposta (que não deve aniquilar o direito) e a vantagem alcançada, o que importa na d) não excessividade.

2 - O defeito maior da vigente lei 9.296, de 24 de julho de 1996, que dispõe sobre interceptações telefônicas e de fluxo de comunicações em sistemas de informática e telemática, talvez consista exatamente na inobservância do princípio da proporcionalidade, quando, por exemplo, permite a interceptação relativamente a todos os crimes punidos com pena de reclusão - no que não observa o princípio da adequação e da não excessividade, estendendo a operação técnica indicada para qualquer tipo de crime, desde que punido com reclusão, e deixando de fora crimes punidos com detenção, mas para os quais a interceptação se apresenta como o meio mais adequado de investigação, como na ameaça cometida por telefone; quando permite o pedido formulado verbalmente, o que evidentemente corrói a verificação da necessidade e da adequação. Mas há outros graves defeitos na lei, como quando transborda da autorização constitucional para prever interceptações de comunicações em sistemas de informática; quando não permite ao acusado o pedido de interceptação; quando não dá vista ao MP do requerimento da diligência pela autoridade policial; quando não dispõe com clareza sobre o incidente probatório no qual deve dar-se conhecimento às partes do conteúdo das operações técnicas, em contraditório pleno; quando omite completamente o tratamento das chamadas "interceptações ambientais"; quando considera a interceptação como único meio de intromissão legal numa comunicação telefônica, olvidando o impedimento, a interrupção, a escuta e gravação. E, sobretudo, a lei em vigor não cuida dos controles necessários a evitar os abusos a que frequientemente sua aplicação deu margem: controles sobre a representação e requerimento da polícia e do Ministério Público, controles sobre a autorização judicial e a forma de seu encaminhamento, controles mais rigorosos sobre os prazos e, sobretudo, controles sobre as operações técnicas, hoje deixadas 
exclusivamente a critério da autoridade policial, sem a fixação de qualquer parâmetro.

3 - O projeto de lei 1258 , de 1995 , do Senador Pedro Simon, aprovado no Senado no mesmo ano, parou nos meandros da Câmara dos Deputados. Referido Projeto era sensivelmente melhor do que a lei que entrou em vigor, retomando muitas das idéias do Projeto Miro Teixeira (projeto $n^{\circ} 3.514 / 89$, aprovado na Câmara dos Deputados). No entanto, decorridos quase dez anos, algumas modificações nas modalidades criminosas justificam a inclusão de novos crimes entre os sujeitos às operações técnicas e, sobretudo, tecnologias mais modernas podem dar o norte para operações técnicas seguras, sob o ponto de vista da inviolabilidade dos elementos probatórios obtidos. O presente Anteprojeto de Lei, ora apresentado pela Comissão instituída pelo Ministro da Justiça Márcio Thomas Bastos, e constituída por Ada Pellegrini Grinover (co-autora do Anteprojeto acolhido pelo Projeto Miro. Teixeira), Antônio Canos de Almeida Castro, Antônio Magalhães Gomes Filho, Antônio Scarance Fernandes e Luis Guilherme Vieira, quer representar uma melhoria e uma modernização do Projeto do Pedro Simon, que por sua vez se inspirava no Projeto Miro Teixeira, aperfeiçoando-o, sem embargo de novidades ditadas pela experiência dos diversos operadores do direito ouvidos. Com efeito, além de ouvir em audiência pública as sugestões da Polícia, Federal e Estadual, do Ministério Público e das prestadoras dos serviços de telefonia, além dos técnicos especialistas nos sistemas operacionais, e além de incorporar diversas idéias apresentadas pelo IBCCrim, a Comissão entrou em contato com a Secretaria de Segurança Pública do Distrito Federal e do Rio Grande do Sul, com a Superintendência da Polícia Federal do Distrito Federal, com o Ministério Público de São Paulo e com os juízes do DIPO de São Paulo, ouvindo, ainda, as prestadoras de serviços de telefonia e a ANATEL. Isso tudo para que, além de avançar nos aspectos jurídicos, o Anteprojeto não ficasse distanciado das modernas técnicas de interferência nas comunicações telefônicas, no intuito de garantir a segurança, a inviolabilidade e a preservação do sigilo.

$4-\mathrm{O}$ Anteprojeto ora apresentado aponta, no art. $1^{\circ}$, as diversas técnicas de interferência na comunicação telefônica: a interceptação (a captação por um terceiro da conversa entre dois interlocutores), o impedimento (a intervenção para que a comunicação não chegue a seu destino), a interrupção (a obstrução da comunicação, em determinado momento), a escuta (a interceptação feita com o conhecimento de um dos interlocutores) e a gravação das conversas captadas. Às comunicações telefônicas são equiparadas todas as formas de telecomunicações, hoje enumeradas na Lei $\mathrm{n}^{\circ}$ 9.472/97. No mesmo artigo, o anteprojeto aponta, em obediência ao princípio da proporcionalidade, os crimes relativamente aos quais a interferência é admissível. $\mathrm{O}$ rol é bastante amplo, de modo a compreender novas modalidades criminosas (como o chamado seqüestro relâmpago ou os crimes contra a ordem tributária), de natureza grave ou particularmente adequadas a serem investigados na forma prevista na lei, como o de ameaça quando cometida por telefone. Logo a seguir, trata das denominadas "interceptações ambientais", tanto de conversas como de sinais eletromagnéticos, óticos ou acústicos, determinando sua sujeição, no que couber, às mesmas regras previstas no Anteprojeto (art. $2^{\circ}$ ). A este, ao contrário, não fica sujeita a gravação de conversa própria, sem conhecimento do interlocutor, 
por telefone ou por outros meios, mas sua divulgação só será permitida para o exercício regular de um direito (art. $4^{\circ}$ ). Desde logo se exclui toda e qualquer intromissão nas comunicações entre o suspeito ou acusado ou seu defensor, de modo mais amplo de quanto o façam a lei em vigor e o projeto Pedro Simon (art. $3^{\circ}$ ). O art. $5^{\circ}$ cuida minuciosamente do pedido, formulado mediante requerimento do MP ou representação da autoridade policial (ciente, neste caso, o MP), que deverá conter todos os elementos, cuidadosamente enumerados, aptos a convencer o juiz da necessidade e da legalidade da operação técnica requerida. Esbatendo uma dúvida prática que tem gerado controvérsia nos tribunais, a lei confere ao MP e à autoridade policial o poder de requisitar das prestadoras dos serviços de telefonia, exclusivamente para os fins de formulação do pedido, o cadastro relativo ao nome, número de telefone e endereço do titular da linha. O suspeito ou acusado, assim como ofendido - quando se trate de ameaça cometida por telefone - também poderão formular o pedido. $\mathrm{O}$ art. $6^{\circ}$ cerca de cuidados a autorização judicial que, precedida de distribuição, e evidentemente fundamentada, deverá referir-se de forma expressa aos pressupostos autorizadores da diligência, taxativamente enumerados. Da decisão que deferir ou indeferir a operação técnica cabe recurso em sentido estrito, sem efeito suspensivo (art. $7^{\circ}$ ). $\mathrm{O}$ art. $8^{\circ}$ toma o cuidado de determinar que o inteiro teor da decisão que autoriza a operação técnica seja transcrita na ordem, a ser assinada pelo juiz e entregue, em duas vias, uma para a prestadora do serviço de telefonia e outra à autoridade policial, com ciência ao MP. Resolve-se, assim, outra questão prática que gerava dúvidas e escapava de controles. Especial cuidado tomam os arts. $9^{\circ} \mathrm{e}$ $10 \mathrm{com}$ os prazos das operações técnicas, exigindo maior controle do juiz sobre os mesmos. $\mathrm{O}$ art. 11 responde a outra dificuldade prática hoje existente, substituindo a precatória por qualquer meio rápido de comunicação, a ser confirmado em 48 horas por documento oficial, quando as operações técnicas devam ser realizadas fora da área de competência do juiz. No caso de falta de comunicação oficial, está prevista a imediata suspensão das operações, pelo juiz, e a inutilização da prova porventura colhida. Especial cuidado mereceram as operações técnicas, durante as quais hoje ocorrem os maiores abusos. Sua execução é atribuída à autoridade policial, sujeita a controle do MP, porquanto o compromisso com o interesse público e com o sigilo, assim como a necessária especialização, desaconselha que a função seja atribuída às operadoras dos serviços de telefonia. Mas o Anteprojeto determina a necessidade de as operações serem efetuadas em órgão próprio, exclusivo e centralizado, sob a responsabilidade direta da Chefia de Polícia. Esses sistemas de gerenciamento centralizado, já existentes em diversos Estados da Federação e no Distrito Federal, asseguram a inviolabilidade da informação obtida, sem engessar as operações. Trata-se de sistema indevassável, cujo padrão deverá ser estabelecido, em 90 dias, pelo Ministério da Justiça, de modo a atender às especificidades das Polícias Federal e Estadual, enquanto caberá à ANATEL, entre outras atribuições, regulamentar o padrão de protocolo a ser utilizado por todas as prestadoras de serviços telecomunicações. Prevê-se a possibilidade de Convênios entre União, Estados e Municípios (arts. 12 a 15). Findas as operações técnicas, a autoridade policial encaminhará imediatamente, em uma única cópia, todo o material obtido ao juiz competente, juntamente com os autos circunstanciados com o resumo das operações realizadas, 
devendo zelar para que nenhum registro fique armazenado no sistema (art. 12, parágrafo único). Recebido o material pelo juiz. tem início o incidente probatório. em contraditório pleno. As partes escutam em juízo as gravações, indicando os trechos cuja transcrição pretendem, sem prejuízo da atividade supletiva do juiz. Dúvidas sobre a autenticidade da gravação ou da voz serão decididas pelo juiz aplicando-se, no que for cabível, as regras do CPP sobre o incidente de falsidade. Da decisão do juiz sobre as transcrições e as dúvidas de autenticidade cabe recurso em sentido estrito, com efeito suspensivo restrito ao incidente probatório (Art. 16). Segundo o art. 17, a transcrição dos trechos indicados instruirá os autos, conservando-se em cartório, em absoluto segredo de justiça, as fitas magnéticas ou elementos análogos, até o trânsito em julgado da sentença. A lei não se preocupa com o incidente de inutilização dos trechos de conversa estranhos à investigação dos crimes, não só porque o produto do Sistema Centralizado é totalmente indevassável, mas. sobretudo porque não se pode retirar das partes o direito de voltar a escutar as gravações, que ainda podem ser úteis à defesa e à acusação. $\mathrm{O}$ art. 18 inaugura o Capítulo atinente à utilização da prova resultante de operações, determinando sua imprestabilidade quando feitas fora dos casos, modalidades e formas previstas na lei. E o art. 19, tratando das operações técnicas lícitas, adverte que a prova delas resultante só pode servir em relação aos crimes para os quais houve autorização, com exceção dos crimes conexos ou de qualquer dos outros crimes constantes do rol do art. $1^{\circ}$. Ademais, não se permite a utilização da prova assim colhida em procedimentos ou processos não-penais. No capítulo VI do Anteprojeto, que cuida das sanções penais, são tipificadas as seguintes condutas: a) proceder às operações de interceptação, impedimento, interrupção, escuta ou gravação de comunicações telefônicas, e das telecomunicações a elas equiparadas para efeito desta lei. fora dos casos, modalidades e formas estabelecidos nesta lei; b) gravar clandestinamente a conversação entre presentes, bem como a proceder à captação ou interceptação ambiental de sinais eletromagnéticos, óticos ou acústicos, registrá-los, analisá-los ou utilizá-los, fora dos casos, modalidades e formas estabelecidos nesta lei; c) divulgar ou utilizar o conteúdo das operações ilegais; d) previsão de qualificadora quando o agente for funcionário público, prevalecendo-se do cargo ou função; e) divulgar ou utilizar, por quaisquer meios, resultado de interceptação, escuta e gravação obtida nos termos desta lei, protegida por sigilo judicial f) divulgar gravação de conversa própria, telefônica ou não, executada sem conhecimento do interlocutor, salvo no caso de exercício regular de um direito; g) fazer afirmação falsa ou induzir a erro a autoridade judicial, com o propósito de obter a autorização; autorizar as operações técnicas fora dos casos, modalidades e formas previstas na lei. Se a divulgação, em qualquer das modalidades tipificadas pela lei, se der por meio de imprensa ou pela internet, prevê-se o aumento de pena de um terço e a apuração da responsabilidade penal segundo os arts. 37 a 39 da Lei $n^{\circ} 5.250$, de 1967. Por último, nas disposições finais e transitórias, prevê-se o segredo de justiça para os inquéritos e processos que contenham elementos informativos ou provas obtidos na forma da lei (art. 27). No artigo 28 , numa disposição transitória, regulamenta-se a forma de execução das operações técnicas, enquanto o Ministério da Justiça e a ANATEL não definirem e regulamentarem o sistema de gerenciamento, atribuindo ao Chefe de Polícia a responsabilidade de estabelecer a 
forma de execução, de modo a possibilitar o controle do Ministério Público e a garantir a regularidade, inviolabilidade e privacidade do sistema utilizado; o art. 29 cuida da entrada em vigor da lei, prevendo uma vacatio le gis de 60 dias; e, finalmente, 0 art. 26 traça a regra de direito intertemporal, pela qual a lei se aplica imediatamente aos processos pendentes, em que não tenha sido observado o disposto nos artigos $1^{\circ}$ e 19 da lei.

5 - Finalmente, a Comissão Especial constituída por Vossa Excelência quer salientar que a filosofia do anteprojeto se funda na ação integrada da Polícia Judiciária e do Ministério Público, bem como na fixação de um sistema unificado de gerenciamento das operações, a ser estabelecido pelo Ministério da Justiça, com a regulamentação das atividades das prestadoras de serviços de telecomunicações, a ser especificada pela ANATEL. Tudo sob o controle do juiz e observados sempre os direitos de defesa, de modo a dotar o Estado de um poderoso meio de investigação, necessário conquanto excepcional, o qual não deve prestar-se a excessos e abusos, mas deve ser perfeitamente adequado aos fins a que se destina.

Brasília, 7 de abril de 2003

Ada Pellegrini Grinover

Antônio Carlos de Almeida Castro

Antônio Magalhães Gomes Filho

Antônio Scarance Fernandes

Luis Guilherme Vieira

\author{
ANTEPROJETO DE LEI \\ Comissão Ministerial \\ Versão final
}

Disciplina o inciso XII, in fine, do artigo $5^{\circ}$ da Constituição Federal e dá outras providências.

O Congresso Nacional decreta:

\title{
CAPÍTULO 1 \\ Da admissibilidade
}

Art. $1^{\circ}$. A interceptação, o impedimento, a interrupção, a escuta e a gravação das comunicações telefônicas somente são admissíveis para fins de investigação criminal ou instrução processual penal relativamente aos seguintes crimes:

I - terrorismo;

II - tráfico de substâncias entorpecentes e drogas afins;

III - tráfico de mulheres e subtração de incapazes;

IV - lavagem de dinheiro;

$\mathrm{V}$ - contra o sistema financeiro nacional;

VI - contra a ordem econômica e tributária;

VII - contra a administração pública, desde que punidos com pena de reclusão; 
VIII - falsificação de moeda;

IX — roubo, extorsão simples, extorsão mediante seqüestro, seqüestro e cárcere privado;

$\mathrm{X}$ - homicídio doloso;

XI - ameaça quando cometida por telefone;

XII - decorrente de organização criminosa.

Parágrafo único. Equiparam-se às comunicações telefônicas, para efeito desta lei, todas as formas de telecomunicação (artigo 60, par. $1^{\circ}$, da Lei $n^{\circ} 4.972 / 97$ ).

Art. $2^{\circ}$. As gravações clandestinas de conversas entre presentes, bem como a captação e a interceptação ambiental de sinas eletromagnéticos, óticos ou acústicos, e o seu registro, análise e utilização, sujeitam-se às mesmas regras previstas nesta lei, no que forem cabíveis.

Art. $3^{\circ}$. As operações referidas nos artigos anteriores não serão permitidas, em qualquer hipótese, quando se tratar de comunicações entre o suspeito ou acusado e seu defensor.

Art. $4^{\circ}$. Não se sujeita a esta lei a gravação de conversa própria, sem conhecimento do interlocutor, por telefone ou por outros meios, mas sua divulgação só será permitida para o exercício regular de um direito.

\section{CAPÍTULO II \\ Do pedido e da autorização judicial}

Art. $5^{\circ}$. O pedido será formulado por escrito ao juiz competente, mediante requerimento do Ministério Público ou representação da autoridade policial, ouvido, neste caso, o Ministério Público, e deverá conter:

I - a clara descrição da situação objeto da investigação;

II - a qualificação do investigado ou esclarecimento pelos quais se possa identificá-lo, salvo impossibilidade manifesta devidamente justificada;

III - a indicação da existência de indícios suficientes da prática de qualquer dos crimes previstos no artigo $1^{\mathbf{0}}$;

IV - a demonstração de ser a operação técnica estritamente necessária e da impossibilidade de ser a prova obtida por outros meios.

$\S 1^{\circ}$. O requerimento ou a representação deverá indicar o número da linha telefônica (código de acesso), com seu código de área, podendo o Ministério Público e a autoridade policial requisitar das prestadoras dos serviços de telefonia, exclusivamente para os fins da formulação do pedido, o cadastro relativo ao nome, número de telefone e endereço do titular da linha.

$\S 2^{\circ}$. O suspeito ou acusado e, no caso do inciso XI do artigo $1^{\circ}$, o ofendido ou seu representante legal, poderá formular o pedido mediante requerimento dirigido ao juiz competente.

Art. $6^{\circ}$. O requerimento ou a representação será distribuído e autuado em separado, sob segredo de justiça, devendo o juiz competente, no prazo máximo de 24 horas, proferir decisão fundamentada, que consignará de forma expressa, quando deferida a autorização; 
a) a existência de indícios suficientes da prática de qualquer dos crimes previstos no artigo $1^{\circ}$;

b) a existência de indícios suficientes de autoria ou participação do investigado em qualquer dos crimes referidos no artigo $1^{\circ}$. salvo impossibilidade manifesta devidamente justificada:

c) a demonstração de ser a providência estritamente necessária, não podendo a prova do crime e de suas circunstâncias ser obtida por outros meios disponíveis;

d) a indicação do número da linha telefônica (código de acesso), incluindo seu código de área, objeto da operação técnica, justificada a sua relação com os fatos investigados.

Art. $7^{\circ}$. Da decisāo que deferir ou indeferir o pedido cabe recurso em sentido estrito, sem efeito suspensivo, devendo o tribunal, se for o caso, determinar a inutilização da prova eventualmente obtida, bem como a sua forma, de modo a preservar a intimidade dos envolvidos.

Art. $8^{\circ}$. O inteiro teor da decisão que autorizar a operação técnica será transcrito na ordem, assinada pessoalmente pelo juiz, a ser expedida em duas vias, uma para a prestadora de serviço de telefonia e outra para a autoridade policial.

Art. $9^{\circ}$. O juiz fixará a duração das operações até o prazo de 15 dias, renovável por igual período, desde que continuem presentes os pressupostos autorizadores da medida.

$\S 1^{\circ}$. Após a primeira renovação, as demais, por igual período, dependerão da verificação da excepcionalidade do caso concreto, baseada na apresentação ao juiz competente de relatório circunstanciado a respeito do resultado das operações já desenvolvidas, não podendo, contudo, o prazo máximo das operações técnicas exceder a 60 dias, exceto quando se tratar de investigação relativa a crime permanente, enquanto não cessar a permanência.

$\S 2^{\circ}$. Para cada prorrogação, será necessária nova ordem judicial, devidamente motivada, observado o disposto no artigo $6^{\circ}$.

Art. 10. Os prazos previstos no artigo $9^{\circ}$ e seus parágrafos correrão de forma contínua e ininterrupta, a partir da data em que a prestadora do serviço de telefonia proporcionar a realização da operação autorizada, comunicando o fato, por escrito, imediatamente ao juiz.

Art. 11. A solicitação de um juiz a outro, para efeito da realização das operações técnicas fora da área de sua competência, será feita por qualquer meio rápido de comunicação, distribuído e autuado sob segredo de justiça, devendo ser confirmada em 48 horas por documento oficial, sem prejuízo do imediato início das operações.

Parágrafo único - Não sendo feita no prazo a comunicação oficial, as operações serão imediatamente suspensas, com inutilização da prova porventura colhida, na forma a ser determinada pelo juiz, de modo a preservar a intimidade dos envolvidos.

\section{CAPÍTULO III \\ Das operações técnicas}

Art. 12. A execução das operações técnicas de que trata esta lei ficará sujeita ao controle do Ministério Público e será efetuada somente pela autoridade policial, 
em órgão próprio, centralizado e exclusivo, sob a responsabilidade direta da Chefia de Polícia.

Parágrafo único. Findas as operações técnicas, a autoridade policial encaminhará imediatamente, em uma única cópia, todo o material obtido ao juiz competente, acompanhado de autos circunstanciados com o resumo das operações realizadas, devendo zelar para que nenhum registro a elas relativo fique armazenado no sistema.

Art. 13. O Ministério da Justiça definirá, no prazo de 90 dias, o padrão de sistema de gerenciamento centralizado, de forma a atender às especificidades das polícias federal e estadual.

$\S 1^{\circ}$ - Definido o sistema descrito neste artigo, a ANATEL regulamentará, no prazo de 90 dias, o padrão de protocolo a ser utilizado por todas as prestadoras de serviços de telecomunicações.

$\S 2^{\circ}$. Sem prejuízo da aplicabilidade imediata do disposto neste artigo, a União, os Estados e o Distrito Federal poderão celebrar convênios para a disciplina do sistema de gerenciamento centralizado, com vistas a assegurar a máxima eficiência. a preservação do sigilo e a inviolabilidade das informações obtidas.

Art. 14. Caberá à ANATEL, no prazo de 90 dias, regulamentar as formas e as condições em que as empresas de telecomunicações prestarão serviços técnicos especializados, quando requisitados pela autoridade policial.

Art. 15. O ressarcimento das empresas pelos serviços prestados e pelo uso da rede de telecomunicações será estabelecido pela ANATEL

\section{CAPÍTULO IV \\ Do incidente probatório}

Art. 16. Recebido o material obtido nas operações técnicas, o juiz competente dará ciência do mesmo ao Ministério Público, ao suspeito ou acusado e seu defensor.

$\S 1^{\circ}$. A partir desse momento e em prazo não inferior a dez dias poderão as partes as examinar os autos circunstanciados e escutar as gravações, indicando, em 48 horas, os trechos cuja transcrição pretendem.

$\S 2^{\mathbf{0}}$. O juiz determinará a transcrição dos trechos indicados pelas partes e pela autoridade policial, bem como de outros que entenda pertinentes e relevantes.

$\S 3^{\circ}$. As dúvidas a respeito da autenticidade da gravação ou da voz serão decididas pelo juiz, aplicando-se, no que couber, o disposto nos arts. 145 a 148 do Código de Processo Penal.

$\S 4^{\circ}$. Das decisões previstas nos parágrafos $2^{\circ}$ e $3^{\circ}$ deste artigo cabe recurso em sentido estrito, com efeito suspensivo restrito ao incidente probatório.

Art. 17. A transcrição dos trechos indicados instruirá os autos, conservando-se em cartório, em absoluto segredo de justiça, as fitas magnéticas ou elementos análogos, até o trânsito em julgado da sentença, quando serão destruídos na forma a ser indicada pelo juiz, de modo a preservar a intimidade dos envolvidos.

Parágrafo único. É permitido às partes extraírem cópias das transcrições e escutarem, em juízo, as gravações, cabendo ao juiz zelar pela preservação da inviolabilidade e privacidade da prova. 


\section{CAPÍTULO V \\ Da utilização da prova resultante das operações}

Art. 18. Os resultados da interceptação, impedimento, interrupção, escuta e gravação, realizados fora dos casos, modalidades e formas estabelecidos nesta lei, não poderão ser utilizados como prova em qualquer investigação, processo ou procedimento, seja qual for sua natureza.

Art. 19. Os resultados das operações técnicas realizadas nos termos desta lei não poderão ser utilizados para a instrução de processos ou investigações relativos a crimes diversos daqueles para os quais a autorização foi dada, salvo quando se tratar de crime conexo ou de outro crime constante do artigo $1^{\circ}$ desta lei, hipótese em que se observará o disposto nos artigos 16 e 17.

Parágrafo único. Serão igualmente inutilizáveis os resultados das operações técnicas em procedimentos ou processos de natureza não-penal.

\section{CAPÍTULO VI \\ Das sanções penais}

Art. 20. Constitui crime proceder à operação de interceptação, impedimento, interrupção, escuta ou gravação de comunicação telefônica e das telecomunicações a ela equiparadas, fora dos casos, modalidades e formas previstas nesta lei.

Pena - reclusão, de 2 (dois) a 4 (quatro) anos, e multa.

$\S 1^{\circ}$. Incorre nas mesmas penas quem divulga ou utiliza o resultado das operações ilegais descritas no caput deste artigo.

$\S 2^{\circ}$. A pena é aumentada de um terço se o agente for funcionário público, prevalecendo-se de seu cargo ou função.

Art. 21. Constitui crime a gravação clandestina de conversa entre presentes, bem como a captação ou a interceptação ambiental de sinais eletromagnéticos, óticos ou acústicos, e o seu registro, análise ou utilização, fora dos casos, modalidades e formas previstas nesta lei.

Pena - reclusão, de 2 (dois) a 4 (quatro) anos, e multa.

$\S 1^{\circ}$ - Incorre nas mesmas penas quem divulga ou utiliza os resultados das operações ilegais descritas no caput deste artigo.

$\S 2^{\circ}-$ A pena é aumentada de um terço se o agente for funcionário público, prevalecendo-se de seu cargo ou função.

Art. 22. Constitui crime divulgar ou utilizar, por quaisquer meios, o resultado das operações técnicas realizadas nos casos, modalidades e formas previstas nesta lei, protegido por sigilo judicial:

Pena - reclusão, de 1 (um) a 3 (três) anos, e multa.

Art. 23. Constitui crime a divulgação da gravação de conversa própria, por telefone ou por outro meio, gravada sem o conhecimento do interlocutor, salvo para o exercício regular de um direito.

Pena - reclusão, de 1 (um) a 3 (três) anos e multa. 
Art. 24. No caso dos crimes previstos nos artigos 20 , parágrafo $1^{\circ}, 21$, parágrafo $1^{\circ}, 22$ e 23 , a pena é aumentada de um terço se a divulgação se der por meio de jornais e outras publicações periódicas, serviços de radiodifusão e serviços noticiosos, bem como pela internet.

Parágrafo único - A responsabilidade penal, nesses casos, será determinada na forma dos artigos 37 a 39 da Lei n. 5.250, de 9 de fevereiro de 1967.

Art. 25. Constitui crime fazer afirmação falsa ou induzir a erro a autoridade judicial, com o propósito de obter autorização para as operações previstas nos artigos $1^{\circ}$ e $2^{\circ}$ desta lei.

Pena - reclusão, de 1 (um) a 3 (três) anos e multa.

Art. 26. Constitui crime autorizar as operações previstas nos artigos $1^{\circ} \mathrm{e} 2^{\circ}$ desta lei fora dos casos, modalidades e formas nela estabelecidas.

Pena - reclusão, de 1 (um) a 3 (três) anos, e multa.

\section{CAPÍTULO VII \\ Disposições finais e transitórias}

Art. 27. Ressalvadas as prerrogativas das partes, correrão em segredo de justiça os inquéritos e processos que contiverem elementos informativos ou provas obtidos na forma desta lei.

Art. 28 - Enquanto o Ministério da Justiça não definir e a ANATEL não regulamentar o sistema de gerenciamento a ser utilizado para as operações técnicas descritas nesta lei, a Chefia de Polícia estabelecerá a forma de sua execução, de modo a possibilitar o controle do Ministério Público e a garantir a regularidade, inviolabilidade e privacidade do sistema utilizado.

Art. 29. Esta lei entrará em vigor 60 (sessenta) dias após sua publicação, aplicando-se, no que forem compatíveis, as normas do Código de Processo Penal e do Código de Processo Penal Militar.

Art. 30. Ficam revogadas as disposições em contrário, e especialmente a lei ${ }^{0}$ 9.296, de 24 de julho de 1996, aplicando-se a nova lei aos processos pendentes, ainda não transitados em julgado, em que não tenha sido observado o disposto nos artigos $1^{\circ}$ e 19 desta lei. 


\section{Revista de Direito Renovar}

Carlos Alberto Menezes Direito e

Luiz Fernando Palhares

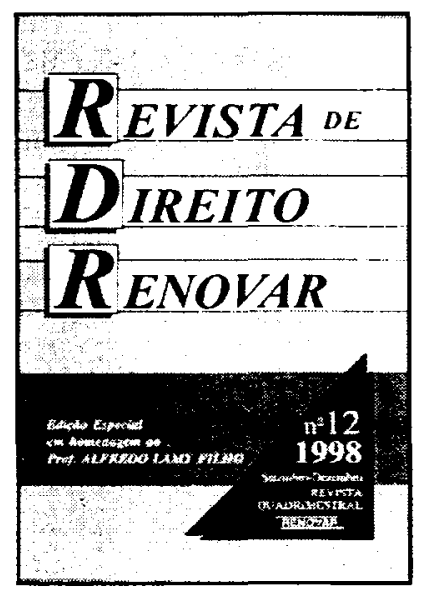

A RDR ocupa um espaço importante na produção jurídica brasileira. Quadrimestralmente, assegura a permanente atualidade dos trabalhos publicados, autorizando maior celeridade entre a produção científica e sua divulgação. A RDR publica, também, a jurisprudência dos Tribunais de todo $o$ país, sendo de repositório útil para juristas, juízes, promotores, advogados e alunos, particularmente facilitada a consulta por um índice bem-estruturado. É publicação indispensável ao lado da Revista de Direito Administrativo, permitindo uma consulta ágil na doutrina e na jurisprudência mais atualizada.

\section{Brochura \\ Form. 15x23 1995}

\section{Ser Advogado Técnicas e Estilo Profissionais}

Alcindo Medeiros Caldas

O autor busca, nesta obra, mexer com o orgulho e com os brios do estudante de Direito e do advogado em geral, alimentando a esperança de que, conhecendo bem a sua profissão, eles a venham respeitar e mesmo a amar, independentemente dos desafios que ela suscite e das recompensas financeiras que seja capaz de propiciar.

Ref. 0126

Form. 14x21
Brochura 1997
MCINDO MEDETROS CALDAS

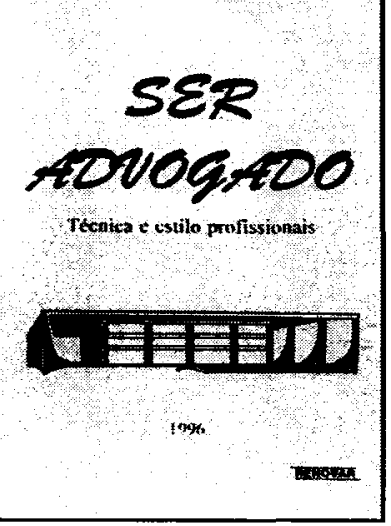

